\title{
HAK IMUNITAS ADVOKAT TERKAIT MELECEHKAN
}

\section{AHLI}

Meirza Aulia Chairani

Fakultas Hukum Universitas Airlangga

Jl. Dharmawangsa Dalam Surabaya Universitas Airlangga, Tel.(031) 5023252, Fax.(031)

502045460286, e-mail: Meirza.aulia@yahoo.com

\begin{abstract}
Abstrak
Advokat merupakan profesi mulia, dalam menjalankan tugas profesinya didasarkan pada iktikada baik. Bebeas mengeluarkan pendapat tidak dapat seenaknya harus berdasarkan peraturan perundang-undangan dan kode etik advokat. Keterangan ahli yang dilecehakan di dalam sidang pengadilan dalam memberikan keteranganya oleh advokat mempunyai hakikat hak imunitas advokat terkait pertanyaan yang melecehkan ahli tidaklah multlak dimiliki oleh advokat yang tidak mempunyai iktikad baik dan sanksi bagi advokat yang melecehkan ahli akan dikenakan tindakan sesuai dengan Pasal 7 Undang-undang No 18 Tahun 2003 tentang advokat dan pencemeran nama baik Pasal 310 KUHP. Advokat dalam menjalankan tugas profesinya dengan iktikad baik tidak melecehkan akan mendapatkan hak imunitasnya. Pendekatan ini menggunakan pendekatan undang-undang dan pendekatan kasus.
\end{abstract}

Kata Kunci: Hak Imunitas Advokat; Iktikad Baik; Keterangan Ahli

\section{A.Pendahuluan}

Sejarah telah membuktikan bahwa hukum dan advokat (law and lawyer) menjadi unsur terpenting bagi suatu tatanan masyarakat, dibelahan dunia mana pun masyarakat tersebut berada. Masyarakat tidak mungkin akan bisa hidup dengan baik tanpa kehadiran law and lawyer. ${ }^{1}$

Advokat merupakan profesi yang mulia, luhur dan terhormat (officium

\footnotetext{
1 Munir Fuady ,(2005), Profesi Mulia (Etika Profesi Hukum Bagi Hakim, Jaksa, Advokat, Notaris Kurator, Dan Penggurus), Bandung: PT Citra Aditya Bakti, hlm. 8
}

nobile), dalam menjalankan tugas profesinya advokat harus berpegang teguh pada peraturan-perundang-undangan dan kode etik advokat.

Advokat sebagai profesi yang bebas dan mandiri dan bertanggung jawab, untuk memberikan keadilan yang berdasarkan hukum untuk pencari keadilan. Advokat sangat diperlukan dalam terselenggaranya peradilan pidana karena advokat mempunyai peran khusus yang berbeda dengan penegak hukum lainya yaitu untuk kepentingan hukum seseorang tersangka, terdakwa dan pihak-pihak pencari 
keadilan, sesuai dengan profesinya sebaagai orang yang memberikan jasa hukum di dalam dan di luar pengadilan. Advokat mempunyai hak imunitas dalam melakukan pekerjaan seperti yang tercantum dalam Undang-Undang No 18 Tahun 2003 tentang advokat (Lembaran Negara Republik Indonesia Tahun 2003 Nomor 49, Tambhan Lembaran Negara Nomor 4288) kemudian disebut (UndangUndang advokat).

Advokat dalam menjalankan tugas dan profesinya mempunyai hak dan kewajiban yang sudah diatur dalam undang-undang advokat dan kode etik advokat. Hak dan kewajiban tersebut diatur di Pasal 14 sampai dengan Pasal 20 undang-undang advokat. Banyak kasus advokat dikenai hukuman karena melakukan tindak pidana. Undang-undang advokat menjelaskan bahwa advokat mempunyai hak imunitas. Hak imunitas ini bahwa advokat tidak dapat dipidana maupun perdata dalam Pasal 16 undangundang advokat.

Advokat bebas dalam menjalankan tugas dan profesinya sebatas untuk membela klienya. Membela klienya pun advokat juga harus mempunyai dasar iktikad baik. Tidak hanya pada kliennya saja tapi juga pada teman sejawat dan juga kepada pihak lawanya.
Kasus terkait advokat yang saat ini terkait advokat yang melakukan melecehkan keterangan ahli. Kasus saat ini terkait kasus tersebut yaitu kasus advokat Basuki Tjahya Purnama yang bernama Humphrey Djemat yang melecehkan keterangan ahli yaitu Ma'aruf Amin. Satu kasus lagi kasus Jessica Kumala Wongso advokatnya yaitu Yudi Wibowo yang melecehkan keterangan ahli yaitu Roni Nitibaskara.

Advokat-advokat

tersebut melakukan perbuatan melecehkan ahli di dalam persidangan. Melecehkan merupakan perbuatan memandang rendah, menghinakan, mengabaikan. undangundang advokat dan kode etik advokat sudah menerangkan batasan-batasan apa yang boleh dan tidak boleh dilakukan oleh advokat.

Keterangan ahli di dalam persidangan keterangan yang disampaikanya menurut pengetahuanya dan ilmu yang dimilikinya, dan tidak mempunyai akibat hukum pada saat menyampaikan keterangannya di dalam sidang pengadilan. Keteragan ahli yang disampaikan di dalam sidang hakim dapat menggunakan keterangan ahli tersebut dan tidak apa-apa kalau tidak menggunakan keterangan tersebut sesuai dengan keyakinan hakim. 
Ahli dalam KUHAP terbatas yaitu dokter kehakiman, dokter atau ahli lainya. Ketentuan tentang keterangan ahli adalah keterangan yang dinyatakan dalam sidang pengadilan. Perlu diperhatikan, karena keterangan ahli dapat juga didapat di luar sidang pengadilan, pada tahap penyidikan demikian pula hendaknya dibedakan keterangan ahli yang dilakuakn dengan sumpah atau janji dan keterangan ahli tanpa sumpah atau janji. ${ }^{2}$

Perbedaan-perbedaan

tersebut berpengaruh terhadap klasifikasi alat bukti. Keterangan ahli yang dinyatakan dalam sidang merupakan alat bukti sebagaimana dimaksud dalam Pasal 184 KUHAP. ${ }^{3}$

Keterangan ahli tidak dibatasi pada suatu tahap pemeriksaan, dan tidak dibatasi hanya dimiliki oleh salah satu pihak yang berperkara. ${ }^{4}$ Advokat dalam melakukan pembelaan kliennya di dalam pengadilan didasari dengan iktikad baik. Berdasar dari hak imunitas advokat, advokat tidak dapat dituntut perdata maupun pidana dalam menjalankan profesinya dengan iktikad baik dalam persidangan. Iktikad baik advokat digunakaan jika mengeluarkan pendapat atau pertanyaan dalam membela perkara

2 Hendar Soetarna,(2011) Hukum Pembuktian Dalam Acara Pidana, Bandung,: PT Alumni, hlm. 69

${ }^{3}$ Ibid

${ }^{4}$ Ibid, hlm.72 yang menjadi tanggungjwabanya dan berpegang pada kode etik profesi dan peraturan perundang-undangan.

Rumusan masalah dalam penelitian hukum ini adalah:

1. Apakah hakikat hak imunitas advokat terkait pertanyaan yang melecehkan ahli?

2. Apa sanksi bagi advokat yang melakukan pertanyaan melecehkan kepada ahli?

\section{B. Metode Penelitian}

Penulisan penelitian hukum ini menggunakan tipe penelitian yuridis normatif (Legal research). Penelitian hukum (Legal research) adalah menemukan kebenaran koherensi, yaitu adakah aturan sesuai norma hukum dan adakah norma yang berupa perintah atau larangan itu sesuai dengan prinsip hukum, serta tindakan (Act) seseorang sesuai dengan norma hukum (bukan sesuai aturan hukum) atau prinsip hukum. ${ }^{5}$

Di dalam Penelitian ini lebih ditujukan kepada Pendekatan undangundang, Pendekatan perundang-undangan dan Pendekatan Konseptual. Perundangundangan (Statute Approach), yaitu pendekatan yang dilakukan dengan menelaah semua peraturan undang-

\footnotetext{
${ }^{5}$ Peter Mahmud Marzuki,(2015), Penelitian Hukum (Edisi Revisi), Jakarta: PT Adhitya Andrebina Agung, hlm. 47.
} 
undangan dan regulasi yang bersangkut paut dengan isu hukum dan fakta hukum yang sedang ditangani dan berhubungan dengan permasalahan yang menjadi pokok bahasan. $^{6}$ Pendekatan Konseptual (conceptual approach), yaitu pendekatan konseptual beranjak dari pandanganpandangan dan doktrin-doktrin yang berkembang di dalam ilmu hukum. $^{7}$ Konsep yang dikaji adalah konsep advokat, konsep hak imunitas, dan konsep keterangan ahli.

Sumber bahan hukum dalam penelitian ini menggunakan bahan hukum primer dan bahan hukum sekunder. Bahan hukum primer merupakan bahan hukum yang bersifat autoritatif, artinya mempunyai otoritas. Bahan hukum primer terdiri dari perundang-undangan, catatancatatan resmi atau risalah dalam pembuatan undang-undang dan putusanputusan hakim. ${ }^{8}$ Bahan hukum sekunder semua publikasi tentang hukum meliputi buku-buku teks, kamus-kamus hukum, jurnal-jurnal hukum, dan komentarkomentar. ${ }^{9}$ Pada penelitian ini yaitu bukubuku terkait tentang advokat, kode etik advokat, hak imunitas advokat, profesi hukum, pembuktian hukum acara pidana, hukum acara pidana.

\footnotetext{
${ }^{6}$ Ibid.,h. 133.

7 Ibid., h. 135

${ }^{8}$ Peter Mahmud Marzuki.Op.Cit, h. 181.

9 Ibid., h. 182
}

\section{Pembahasan}

Hakikat Hak Imunitas Advokat

Seorang advokat dalam menjalankan tugasnya sebagai penegak hukum sejajar dengan polisi, jaksa, dan hakim didepan hukum dan undang-undang memiliki hak imunitas. Advokat sendiri dalam menjalankan profesinya dalam membela klienya mempunyai hak imunitas yaitu hak yang tidak dapat dituntut baik secara perdata maupun pidana dalam menjalankan tugas profesinya dengan iktikad baik untuk kepentingan klienya dalam sidang pengadilan. Hal ini diatur dalam Pasal 16 undang-undang advokat, memberikan jasa hukum dan mendampingi klienya didalam pengadilan.

Mahkamah Konstutusi mengabulkan permohonan perkara 26/PPUU-XI/2013, pengujian Pasal 16 undang-undang advokat yang terkenal sebagai hak imunitas advokat yang diajukan oleh sejumlah advokat. Menurut Mahkamah Konstutusi, advokat dalam memberikan bantuan hukum, konsultasi hukum, menjalankan kuasanya, mendampingi, membela dan melakukan tindakan hukum lainya untuk kepentingan klien dapat dilakukan di dalam maupun diluar pengadilan. ${ }^{10}$

\footnotetext{
${ }^{10} \mathrm{MK}$ Tegaskan Imunitas Advokat Di Dalam dan Luar Pengadilan, (2017) ,Tersedia pada http://www.mahkamahkonstitusi.go.id/index.php?p
} 
Istilah hak imunitas tidak ditemukan dalam undang-undang advokat tetapi, untuk memahami pengertian hak imunitas, dapat memulainya dari pengertian hak. Hak dapat didefinisikan alokasi kekuasaan kepada seseorang secara tersetruktur dalam arti keluasan dan kedalamanya. ${ }^{11}$ Dari asal-usul kata, istilah imunitas dapat ditelususri ke immunis, kata Latin yang antara lain berarti pembebasan dari kewajiban umum, kebebasan/ pembebasan/ pajak/ kewajiban militer/ pekerjaan rodi, hak istimewa. ${ }^{12}$

Advokat dalam menjalankan tugas profesinya dijamin kebebasanya, tidak serta-merta diberi imunitas. Kebebasan dan imunitas itu tidak absolut, tetapi dengan batas-batas tertentu,yakni batas Pasal 14 dan Pasal 15 undang-undang advokat: kode etik profesi dan peraturan perundang-undangan (Pasal 14 dan Pasal 15 undang-undang advokat) serta iktikad baik (Pasal 16 undang-undang advokat). Setiap tindakan yang melampaui atau diluar tiga hal itu, tidak bisa dilindungi oleh hak imunitas. ${ }^{13}$

age=web. Berita\&id=9899\#.Whp7JZdx3IU, [Akses pada tanggal 23 september 2017].

${ }^{11}$ Satjipto Rahardjo,(2006), Ilmu Hukum, Bandung : PT Citra Aditya Bakti,hlm. 53

12 K. Prent C.M., J. Adisubrata, \& W.J.S. Poerwadarminta, (1969),Kamus Latin-Indonesia, Yogyakarta: Kanisius,hlm. 29.

13 Theodorus Yosep Parera,(2016), Advokat Dan Penegak Hukum, Yogyakarta: Genta, . hlm. 128
Hak advokat salah satu yang penting dalam menjalankan profesinya adalah hak atas kebebasan menjalankan fungsi sebagai penasihat hukum. Terkait dengan kebebasan,seorang advokat tidak boleh dihukum atau diancam hukuman, baik itu hukum pidana, hukum perdata, adminitratif, ekonomi maupun sanksi ataupun intimindasi lainya dalam pekerjaanya membela dan memberi nasehat kepada klien. ${ }^{14}$

Menurut Otto Hasibuan, lingkup hak imunitas advokat seharusnya meliputi juga tindakan di luar persidangan. Adanya iktikad baik dari advokat yang bersangkutan dan tindajan tersebut dalam lingkup tugas profesinya. Tanpa iktikad baik, seorang advokat tidak memiliki imunitas sehingga layak di proses secara hukum. $^{15}$

Pemberian hak imunitas untuk advokat dengan tujuan agar dijamin oleh undang-undang dalam membela kepentingan klienya, dan tidak dihinggapi rasa takut pada saat membela. Advokat harus dilindungi dan merasa aman oleh negara dalam melaksanakan tugas profesinya dalam membela klienya, oleh

14 Frans Hendra Winarta,(1995), Advokat Indonesia, Citra, Idealisme Dan Keprihatinan, Jakarta: Pustaka Sinar Harapan , hlm. 57.

${ }^{15}$ Hak Imunitas Advokat Tergantung Iktikad Baik , (2017),Tersedia pada: http://www.hukumonline.com/berita/baca/hol15478 /hak-imunitas-advokat-tergantung-iktikad-baik, , [Akses pada tanggal 09 mei 2017]. 
karena itu advokat diberi perlindungan hak imunitas dengan tidak melanggar hukum dan pearturan perundang-undangan.

\section{Hak Imunitas Terkait Iktikad Baik}

Keberlakuan hak imunitas melekat pada advokat dengan persyaratan utama bahwa advokat melakukan tugas-tugas/ pekerjaanya dengan iktikad baik. Pengertian iktikad baik dapat ditelusuri melalui bagaimana frase ini diungkapkan dalam bahasa asing: In good faith (Inggris) dan de bonne fot (Perancis). Iktikad baik merupakan sendi dalam hukum perjanjian. $^{16}$

Pengertian iktikad baik dalam Kamus Istilah Hukum Fockema Andre Belanda-Indoensia yang mengatakan : iktikad baik (goede trow) berarti maksud, semangat yang menjiwai para peserta dalam hubungan hukum. Dari definisi iktikad baik ini dapat mempunyai arti dua hal yaitu $:^{17}$

1. Definisi ini dapat melengkapi hal-hal umum, sehingga dapat diterapkan dalam hubungan keperdataan maupun hubungan kepidanaan.

${ }^{16}$ Subekti,2005, Hukum Perjanjian, Jakarta: PT Intermasa, hlm.41

${ }^{17}$ N.E. Algra \& H.R.W. Gokkel. Kamus Istilah Hukum Fockeman Andre Belanda-Indonesia, terjemahan Saleh Adiwinanta S.H. dkk, Binacipta, Bandung, 1983, hlm. 419 di Dalam V.Harlen Sinaga, Dasar-Dasar Pokok Profesi Advokat, Jakarta: Erlangga, 2010, hlm.216
2. Pengertian ini tidak dikaitkan dengan peraturan perundang-undangan atau norma hukum, melainkan lebih dari itu menyangkut latar belakamg maksud dan semangat yang menjiwai mengapa suatu perbuatan dilakukan oleh advokat dalam menjalankan tugasnya.

Perjanjian didalamnya Pasal 1338 ayat (3) BW menyatakan bahwa perjanjian-perjanjian harus dilaksanakan dengan iktikad baik. Apa yang dimaksud dengan iktikad baik (te goeder trouw; good faith), perundang-undangan tidak memberikan definisi yang tegas dan jelas. Dalam Kamus Besar Bahasa Indonesia, yang dimaksud dengan iktikad adalah kepercayaan, keyakinan yang teguh,maksud, kemauan (yang baik). ${ }^{18}$

Hak imunitas advokat hanya berlaku selama pada saat advokat melaksanakan tugas profesinya. Penggunaan hak imunitas advokat tentu harus didasarkan pada iktikad baik dari dalam diri advokat itu sendiri. Iktikad baik yang menjadi dasar hak imunitas advokat berarti bahwa dalam menjalankan tugas profesinya maka advokat wajib mematuhi dan tidak melanggar peraturan perundang-undangan dan kode etik advokat.

\footnotetext{
${ }^{18}$ Agus Yudha Hernoko,(2014), Hukum Perjanjian Asas Proporsionalitas Dalam Kontrak Komersial (edisi Pertama), Jakarta: PT Kharisma Putra utama, hlm. 134.
} 
Perlu ada batasan permaknaan terhadap bunyi Pasal 16 undang-undang advokat tersebutkhususnya frase".... dalam menjalankan tugas profesinya dengan iktikada baik untuk kepentingan pembelaan klien dalam sidang pengadilan". Artinya bahwa advokat dalam menjalankan profesinya harus benar-benar berdasarkan hukum dan kode etik advokat (canons of ethics).

Profesi hukum menuntut persyaratan dan standarisasi yang tinggi terhadap seorang advokat dalam menjalankan profesinya karena profesi advokat bersinggungan dengan penerapan hukum dan nilai etika. Advokat dalam menjalankan profesinya tidak diperbolehkan melakukan hal-hal yang justru melanggar hukum dan kode etik advokat dengan berlindung dibalik hak imunitas. ${ }^{19}$

Tindakan advokat yang merasa pihak lawan merasa dirugikan dapat menempuh upaya hukum dapat mengajukan tuntutan hukum memalaui jalur pidana. Dengan demikian advokat membela kepentingan klienya yang tidak didasarkan pada iktikad baik dan untuk kepentingan klienya yang sedang dibelanya dapat dikenakan tindakan dari penegak hukum. Dengan tidak ada iktikad baik dalam menjalankan

19 Solehoddin, (2015),Menakar Hak Imunitas Profesi Advokat, Rechtldee Jurnal Hukum, Vol 10 No.1 Juni 2015,Malang, hlm. 113 tugas profesinya maka advokat tidak dapat mendapatkan hak imnuitas yang terdapat dalam Pasal 16 undang-undang advokat. Dilaksanakanya iktikad baik merupakan bentuk kepatuhan terhadap hukum dan melekatlah hak imunitas advokat tersebut. Hak imunitas diberikan kepada advokat harus mengedepankan hak dan kewajiaban yaitu iktikad baik dalam menjalankan tugsa profesinya sebagai advokat.

\section{c. Parameter Pertanyaan Advokat}

Melecehkan Ahli

Seorang advokat itu adalah termasuk makhluk bermoral, dan juga seorang pribadi. Karena merupakan seorang pribadi maka seorang advokat mempunyai pendapat sendiri, perasaan sendiri, yang dengan itu seorang advokat berbuat atau bertindak. Dalam hal ini seorang advokat tidak luput dari kesalahan, kekeliruan, baik yang disengaja maupun tidak disengaja. Oleh karena itu seorang advokat di dalam menjalankan tugasnya bertanggung jawab terhadap negara, masyarakat, pengadilan, klien, tuhan dan pihak lawanya. ${ }^{20}$

Kasus terbaru terkait advokat didalam persidangan, advokat dalam melakukan tugasnya membela klienya juga harus memperhatikan batasan-batasan sebagai advokat yang sudah diatur dalam

\footnotetext{
${ }^{20}$ Ishaq, (2010), Pendidikan Advokat, Jakarta: Sinar Grafika, hlm.44
} 
kode etik advokat dan peraturan perundang-undangan. Membela klien dengan membuat pertanyaan-pertanyaan atau pendapat-pendapat yang menyudutkan dan menunjukan sikap tidak hormat terhadap hukum tidak dibenarkan.

Contoh kasus yang ada saat ini Gubernur Jakarta Basuki Tjahaja Purnama (Ahok) atas kasus penodaan agama. Pada saat pembuktian dari pihak Jaksa mendatangkan ahli salah satunya yaitu Ketua Umum MUI Ma'ruf Amin. Ahok pun menggunkan advokat dalam membela kasusnya salah satunya Humphrey Djemat.

Majelis Ulama Indonesia (MUI) menilai cecaran pertanyaan pihak Basuki Tjahaja Purnama (Ahok) kepada ketuanya, KH Ma'ruf Amin dalam persidangan kasus dugaan penistaan agama, Selasa 31 Januari 2017 merupakan tindakan brutal. Tindakan pihak Ahok terhadap Ma'ruf Amin itu dinilai tidak elok dilakukan.

Terlebih, kapasitas Ma'ruf Amin hanya sebagai saksi dalam persidangan kasus tersebut. "Kami menyatakan sikap bahwa tindakan-tindakan yang dilakukan Ahok dan pengacara tidak elok, brutal, dan liar terhadap tokoh yang dihadirkan sebagai saksi," ujar Ketua Komisi Hukum MUI Ikhsan Abdullah dalam diskusi Polemik SINDO Trijaya Network bertajuk
Ngeri-ngeri Sadap di Warung Daun, Cikini, Jakarta Pusat, Sabtu (4/2/2017). ${ }^{21}$

Dirinya pun mengatakan, seharusnya Ahok beserta pengacara bisa membedakan Ma'ruf Amin dengan saksi-saksi pelapor lainnya. Sebab, Ma'ruf Amin bersedia menghadiri persidangan dengan niat menghormati panggilan hukum.

"Karenanya kemarin kami langsung menyampaikan ke Mahkamah Agung, Mahkamah Konstitusi, dan kami juga lagi minta pertimbangan Peradi untuk menilai lebih lanjut sikap pengacara ini," pungkasnya.

Diketahui, dalam sidang lanjutan tersebut Ahok dan tim advokatnya menuding Ma'ruf tidak pantas menjadi saksi karena dinilai tidak objektif dalam persidangan. Ahok menuding Ma'ruf mendukung salah satu pasangan calon gubernur dan wakil gubernur DKI Jakarta. Bahkan, juga mengancam akan memproses secara hukum Ma'ruf dan sesumbar punya data yang sangat lengkap soal pembicaraan Ma'ruf dan SBY.

Kasus lainya yaitu kasus pembunuhan Mirna Salihin yang dilakukan oleh Jessica Kumala Wongso. Pada saat Jaksa mendatangkan ahli

21 MUI: Tindakan Ahok dan Pengacaranya Terhadap Ma'aruf Amin Brutal, (2017), Tersedia Pada: https://nasional.sindonews.com/read/117702 5/13/mui-tindakan-ahok-dan-pengacaranyaterhadap-maruf-amin-brutal-1486204867, , [Akses pada tanggal 18 Mei 2017].

Volume 2 No.1 April 2018

ISSN Cetak: 2579-9983, E-ISSN: 2579-6380

Halaman. 144-163 
penasehat kriminologi dalam persidangan, advokat Jessica yaitu Yudi wibowo dan Otto hasibuan.Sidang kasus kopi sianida diwarnai sikap emosional salah satu advokat terdakwa, Yudi Wibowo. Ia menyangsikan keterangan saksi ahli Roni Nitibaskara. Terlebih sebagai ahli, Yudi menganggap paparan penasehat kriminologi Kapolri itu justru membeberkan fakta dan sisi buruk Jessica.

"Dari tadi anda membaca sisi buruk, bisa tidak menganalisis sisi baik Jessica," ujar Yudi kepada Roni, di ruang sidang PN Jakarta Pusat, Kamis (1/9/2016). ${ }^{22}$ Namun, Roni justru menjawab singkat dan membuat Yudi emosional. "Emang saya harus mengagumi Jessica?" sanggah Roni. "Anda ini saksi ahli, doktor, profesor pula," sambung Yudi.

Melihat perdebatan itu, JPU langsung menginterupsi sidang dan meminta ketua majelis hakim untuk bersikap bijak. "Instruksi yang mulia, advokat sudah emosional," timpal JPU disambut tepuk tangan tamu persidangan. Selanjutnya, ketua majelis hakim Kisworo lalu memperingatkan advokat untuk tenang. Seperti diketahui, hari ini JPU menghadirkan dua saksi ahli, keduanya

22 Ungkap Sisi Buruk Jessica, Pengacara "Semprot"Saksi Ahli, (2017) Tersedia Pada: http://news.okezone.com/read/2016/09/01/338/147 8570/ungkap-sisi-buruk-jessica-pengacarasemprot-saksi-ahli, [Akses pada tanggal 18 Mei 2017] ialah Roni Nitibaskara dan Sarlito Wirawan.

Keterangan ahli itu sendiri mempunyai arti keterangan seseorang di bawah sumpah mengenai suatu hal menurut pengetahuan dan pendapat berdasarkan bidang keahliannya yang bersangkutan. $^{23}$ Advokat dalam kasus diatas melakukan perbuatan melecehkan keterangan yang diberikan oleh ahli. Meskipun advokat tersbeut membela kliennya keterangan ahli dalam persidangan memberikan keterangan berdasarkan ilmu pengetahuan yang dimilikinya dan tidak mempunyai akibat hukum. ${ }^{24}$

Meleceh sendiri dalam Kamus Besar Bahasa Indonesia mempunyai arti menghinakan, memandang rendah (tidak berharga), mengabaikan orang sering dia karena perbuatanya itu. Melecehkan artinya memandang rendah (tidak berharga), menghinakan, mengabaikan. ${ }^{25}$

Melecehkan mempunyai sinonim yaitu melanyak, melatakan, memudahkan, memunggungi, mencapak, mencebikkan, mendaifkan, mengabaikan, mengecilkan,

\footnotetext{
23 Jimli Asshiddiqie, (2010),Hukum Acara Pidana Pengujian Undang-Undang, Jakarta: Sinar Grafika, hlm. 161

${ }^{24}$ Didik Endro Purwoleksono(2015), Hukum Acara Pidana,Suarabaya: Airlangga University Press, hlm.117

${ }^{25}$ Kamus Besar Bahasa Indonesia (Edisi Ketiga), (2002), Pusat Bahasa Departemen Pendidikan Nasional, Jakarta: Balai Pustaka, hlm. 650
} 
menggampangkan,

menghinakan,

meniadakan, menistakan, menyambillalukan, menyampingkan, menyepelekan, meranca, meremehkan, merendahkan, meringankan. ${ }^{26}$

Pertanyaan advokat tersebut di dalam persidangan melecehkan keterangan yang disampaikan oleh ahli. Ahli dalam menyampaikan keterangannya di dalam pengadilan menyampaikan berdasarkan ilmu yang dimilikinya. Jadi seorang advokat tidak boleh menentukan bahwa keterangan ahli itu tidak benar. Keyakinan hakimlah yang menentukan keterangan ahli tersebut digunakanya atau tidak dan advokat tidak diperbolehkan menyatakan keterangan tersebut benar atau tidak benar. Sesuai dengan pasal 183 KUHAP yang disebutkan: hakim tidak boleh menjatuhkan pidana kepada seseorang kecuali apabila sekurang-kurangnya dua alat bukti yang sah ia memperoleh keyakinan hakim bahwa suatu tindak pidana benar-benar terjadi dan bahwa terdakwalah yang bersalah melakukanya.

Di indonesia menggunakan teori pembuktian berdasarkan undang-undang secara negatif (Negatief Wettelijk) teori ini dengan tegas menyatakan bahwa pembuktian harus didasarkan kepada ketentuan undang-undang dan keyakian

26 http://www.sinonimkata.com/sinonim-156122melecehkan.html, [Akses pada tanggal 07 September 2017]. hakim. Yang dimaksud ketentuan berdasar undang-undang adalah terpenuhinya sekurang-kurangnya ada dua alat bukti yang sah atau alat bukti yang ditentukan undang-undang, yang mendukung dakwaan. Sedangkan pengertian keyakinan hakim dalam teori tersebut adalah keyakinan yang diperoleh dari sekurangkurangnya dua alat bukti yang sah. ${ }^{27}$

Seorang advokat tidak pernah diperkenankan mengucapkan tuduhantuduhan yang menyakiti hati pihak lawan dan yang melebihi apa yang diperlukam untuk memenuhi tugasnya. Kebebasan berbicara seorang advokat sesungguhnya tidak lebih besar daripada kebebasan berbicara rakyat biasa pada umumnya. Para advokat diharapkan sedapat mungkin menjauhkan diri dari kecenderungan untuk melukiskan secara gelap (diepgrijs) kelakuan dan tujuan dari pihak lawan, serta dari penghinaan sebagaimana dengan kepentingan tugas umum darma baktinya penegakan keadilan dan perhatian terhadap kepentingan justitiable atau klien. ${ }^{28}$

Advokat dapat dikenakan tindakan karena alasam sesuai dengan Pasal 6 huruf (b) dan huruf (c) undang-undang advokat sesuai dengan kasus diatas yaitu :

\footnotetext{
${ }^{27}$ Hendar Soetarna,Op.Cit., hlm. 41

28 E. Sumaryono, (1995),Etika Profesi Hukum Norma-Norma Bagi Penegak Hukum, Yogyakarta: Kanisius, hlm. 157
} 
b. Berbuat atau bertingkah laku yang tidak patut terhadap lawan atau rekan seprofesi

c. bersikap, bertingkah laku, bertutur kata, atau mengeluarkan pernyataan yang menunjukkan sikap tidak hormat terhadap hukum, peraturan perundangundangan atau pengadilan

Ketentuan Pasal 6 undang-undang advokat, memang bisa saja seorang advokat sebagai penegak hukum tempat masyarakat mengadukan nasibnya melakukan perbuatan-perbuatan tidak baik, karena tidak dapat dipungkiri bahwa dunia hukum saat ini menjadi buram atau hitam diakaibatkan sebagian pengacara atau advokat yang tidak benar menjalankan profesinya, bahkan sering kali menyalahgunakan hukum itu sendiri. ${ }^{29}$

Pasal 6 undang-undang advokat ini sudah menjelaskan bahwa advokat dilarang melakukan perbutan-perbuatan yang terdapat dalam Pasal 6 undangundang advokat jika mereka tetap melakukan perbuatan tersebut maka akan dikenakan sanksi. Seperti halnya kasus diatas advokat yang kata-kata, perbuatanya nya saat di dalam persidangan melecehkan atau memandang rendah keterangan ahli tersebut dapat dikenakan tindakan sesuai dalam Pasal 6 undang-undang advokat.

29 Supriadi,(2010), Etika \& Tanggung Jawab Profesi Hukum Di Inonesia, Jakarta: Sinar Grafika, hlm. 64 .
Tata Cara Memeriksa Dan Mengadili Pelanggaran Kode Etik Profesi Advokat Keberadaan advokat sangat diperlukan apabila dikaitkan dengan dunia peradilan, hal ini sebgaimana tercantum dalam konsideran hukum dalam undangundang advokat, yang bunyinya: "Kekuasaan kehakiman yang bebas dari segala campur tangan dan pengaruh dari luar, memerlukan advokat yang bebas, mandiri dan bertanggung jawab, untuk terselenggranya suatu peradilan yang jujur, adil , dan memiliki kepastian hukum bagi semua pencari keadilan dalam menegakkan hukum, kebenaran, keadilam dan hak asasi manusia."30

Undang-undang advokat dan kode etik advokat Indonesia ,merupakan Ius costitutum (hukum positif) yang mengatur prilaku advokat sebagaimana seharusnya. Perbedaanya adalah bahwa kode etik advokat Indonesia memuat tata cara atau aturan yang berkaitan dengan akhalak atau moral advokat secara rinci dalam melakukan tugasnya sehari-hari. Sedangkan undag-undang advokat berisikan hal-ak yang umum dan lebih luas mengenai kehidupan advokat seperti pengangkatan, sumpah, status, penindakan, pemberhentian, pengawasan, hak dan

\footnotetext{
${ }^{30}$ Isrok,(2009), Advokat Sebagai Penegak Hukum, Varia Peradilan Majalah Hukum, Tahun XXIV No 283 Juni 2009, Ikatan Hakim Indonesia, Jakarta, hlm. 27.
} 
kewajiban, honorarium, bantuan hukum Cuma-Cuma, advokat asing. ${ }^{31}$

Advokat jika diketahui melakukan perbuatan-perbuatan yang dilarang dalam undang-undang advokat dan kode etik advokat mendapat hukuman dari Dewan Kehormatan Organisasi Advokat dimana advokat tersebut bernaung. Perlu adanya pengawasan terhadap advokat, pengawasan tersebut adalah agar advokat dalam menjalankan profesinya selalu menjunjung tinggi kode etik advokat dan peraturan serta perundang-undangan yang berlaku.

Pasal 1 huruf (e) kode etik advokat disebutkan:

Dewan Kehormatan adalah lembaga atau badan yang dibentuk oleh Organisasi Profesi Advokat yang berfungsi dan berkewenangan mengawasi pelaksanaan kode etik advokat sebagaimana mestinya oleh advokat dan berhak menerima dan memeriksa pengaduan terhadap seorang advokat yang dianggap melanggar kode etik advokat

Pasal 13 ayat (1) undang-undang advokat, pengawasan sehari-hari terhadap advokat sekarang dilakukan oleh Komisi Pengawas, yang terdiri atas advokat senior, ahli atau akademisi dan mayarakat.

Berdasarkan prespektif sejarah, pengawasan advokat dilakukan melalui dua cara, yaitu pengawasan internal dan

31 V.Harlen Sinaga,(2011), Dasar-Dasar Profesi Advokat, Jakarta: Erlangga,hlm. 84 eksternal. Pengawasan internal dilakukan oleh Dewan Kehormatan Profesi yang pada masa orde baru tidak bisa berjalan dengan karena banyak campur tangan pemerintah dalam organisasi profesi, sedangkan pengawasan eksternal dilakukan oleh badan-badan peradilan yang berdasarkan amanat undang-undang diberikan kewenangan untuk melakukan hal tersebut. ${ }^{32}$

Fungsi pengawasan karena telah ditentukan bahwa Komisi Pengawasan menjadi salah satu subyek hukum pengadu, pengaduan dapat diajukan oleh pihak-pihak yang berkepentingan dan merasa dirugikan sebagaimana diatur dalam pasal 11 ayat (1) Kode etik advokat yaitu:

a. Klien

b. Teman sejawat Advokat

c. Komisi pengawas

d. Pejabat pemerintah

e. Anggota masyarakat

f. Dewan Pimpinan Cabang/ Pusat/ Cabang/ Daerah Dan Organisasi Profesi dimana teradu menjadi anggota

Untuk mengefektifkan menganai adanya pengaduan yang diajukan oleh yang merasa dirugikan yang dirugikan

32 Agus Raharjo dan Sunaryo,(2014),Penilaian Profesionalisme Advokat Dalam Penegakan Hukum Melalui Pengukuran Indikator Kinerja Etis,Jurnal Media Hukum, Vol 21 No. 2 Desember 2014,Jawa tengah, hlm. 191

Volume 2 No.1 April 2018

ISSN Cetak: 2579-9983, E-ISSN: 2579-6380

Halaman. 144-163 
oleh advokat maka dalam Pasal 12 ayat (1) kode etik advokat disebutkan:

a. Pengaduan terhadap advokat sebagai teradu yang dianggap melanggar kode etik harus disampaikan secara tertulis disertai dengan alasan-alasannya kepada Dewan Kehormatan Cabang/Daerah atau kepada Kepala Dewan Pimpinan Cabang/ Daerah atau Dewan Pimpinan Pusat dimana teradu menjadi anggota.

Seseorang melakukan pengaduan karena dia merasa telah dirugikan atas dugaan pelanggaran terhadap kode etik advokat oleh advokat dalam melakukan pekerjaanya. Pengaduan terhadap tindakan advokat dibuat secara tertulis, yang disertai dengan alasan-alasanya yang diajukan kepada Dewan Kehormatan Cabang/ Daerah atau kepada Dewan Pimpinan Cabang/ Daerah atau Dewan Pimpinan Pusat dimana teradu berdomisili.

Dewan Kehormatan Cabang/Daerah dalam melakukan sidang pemeriksaan kepada advokat yang dituduh telah melakukan pelanggaran kode etik advokat ini dilakukan dengan sekurang-kuranya 3 (tiga) orang anggota, hal ini di jelaskan dalam Pasal 14 kode etik advokat.

Setelah melakukan pengaduan terhadap Dewan Kehormatan dilakukan pemeriksaan dalam persidangan dan perdamaian. Persidangan dugaan pelanggran kode etik advokat hampir sama dengan proses persidangan dalam perkara perdata di pengadilan. Urut-urutan acara persidangan adalah gugatan, jawaban, replik, duplik, pembuktian tertulis, pembuktian saksi-saksi, kesimpulan, dan putusan. Namun terdapat perbedaan dua hal yaitu dalam persidangan dugaan pelanggaran kode etik, acara persidangan dapat dipersingkat dan subtansi pelanggran menentukan apakah perdamaian dapat ditempuh atau tidak. ${ }^{33}$

Tata cara pemeriksaan oleh Dewan Kehormatan Cabang, yang pertama-tama Dewan Kehormatan menerima pengaduan dalam bentuk tertulis yang disertai dengan surat-surat bukti dan kesaksian-kesaksian yang dianggap perlu dan diserahkan selambat-lambanya 14 (empat belas) hari, dan dikirim dengan tanda terima sebagai bukti. Surat pemberitahuan dengan lampiran surat pengaduan selengkapnya tersebut harus secara patut disampaikan kepada yang diadukan dengan diberitahukan supaya jawaban disampaikan secara tertulis kepada Dewan Kehormatan Cabang selambat-lambatnya dalam waktu 21 (dua puluh satu) hari terhitung sejak tanggal diterimanya.

Jawaban tertulis disampaikan kepada Dewan Kehormatan Cabang disertakan dengan surat-surat bukti dan 
kesaksian yang dianggap perlu. Jika jawaban tertulis dalam waktu 21 (dua puluh satu ) hari yang diadukan tidak memebrikan jawaban tertulisnya maka pemebritahuan ulang ke dua kalinya dengan peringatan supaya jawaban secara tertulis tersebut disampaikan dalam waktu 14 (emat belas) hari tersebut tidak memberikan jawabanya maka dianggap melepaskan hak jawabnya. Apabila pengadu tidak memberikan jawaban tertulis, pemeberitahuan ulang ke dua kalinya dengan peringatan supaya jawaban secara tertulis disampaikan, maka pengadu melepaskan hak jawabnya. Apabila yang tidak hadir adalah pihak yang diadukan pemeriksaan tetap diteruskan tanpa hadirnya yang diadukan.Dewan

Kehormatan Cabang berkuasa memeriksa dan mengadili serta menjatuhkan putusan tanpa kehadiran pihak yang diadukan dengan putusan verstek.

Menentukan waktu sidang dalam waktu 21 (dua puluh satu) hari dan menyampaikan surat panggilan kepada kedua belah pihak yaitu pengadu dan diadkan paling lambat 3 (tiga) hari sebelum sidang dilakukan secara patut. Pengadu dan didukan dapat didampingi oleh penasehatnya tetapi tidak boleh diwakilkan dan dikuasakan kepada orang lain.
Pada sidang pertama kali, kedua belah pihak pengadu dan diadukan dipanggil hadir dalam persidangan dengan patut. Apabila pengadu tidak hadir dalam sidang pertana setelah dipanggil dan sidang kedua tidak hadir dengan tanpa alasan yang sah maka pengaduan dari pengadu dianggap tidak sah atau gugur dan tidak dapat diajukan kembali. Apaabila sudah dipanggil yang diadukan pada sidang pertama dan sidangkedua tidak hadir tanpa alasan yang sah, maka Dewan Kehormatan Cabang berkewenangan melanjutkan sidang dan menjatuhkan putusan tanpa hadirnya yang diadukan. Dewan Kehormatan Cabang mengusahakan antara kedua belah pihak untuk tercapainya perdamaian, apabila perdaiaman terwujud maka pengadu mencabut dan membatalkan pengaduannya dan membuat akta perdamaian yang mempunyai kekuatan hukum tetap dan dijadikan keputusan Dewan Kehormatan Cabang.

Apabila tidak terjadi perdamaian diantara kedua belah pihak maka pengadu diminta mengemukakan alasan-alasan pengaduanya kepada diadukan untuk mengemukakan hak pembelaan dirinya yang dilakukan secar bergiliran. Suratsurat bukti dan keterangan kesaksian saksisaksi dari pengadu dan dari diadukan akan dipriksa oleh Dewan Kehormatan Cabang. 
Putusan dari pengaduan terhadap pelanggaran kode etik advokat Pasal 15 kode etik advokat: setelah memeriksa dan mempertimbangkan pengaduan, pembelaa$\mathrm{n}$, surat-surat bukti dan keterangan saksisaksi maka Mejelis Dewan Kehormatan mengambil keputusan yang dapat berupa :

a. Menyatakan pengaduan dari pengadu tidak dapat diterima;

Putusan ini berkaitan dengan pengadila mana yang seharunya mengadili, ke pengadilan wilayah mana seharusnya diajukan.

b. Menerima pengaduan dari pengadu dan mengadili serta menjatuhklan sanskisanksi kepada teradu;

Apabila dalam pemeriksaan advokat ditemukan bersalah, sanksi akan dijatuhkan pada yang bersangkutan. Amar putusan: " Menerima Pengaduan Dari Pengadu Dan Mengadili Serta Menjatuhkan Sanksi-Sanksi Kepada Teradu".

c. Menolak pengaduan dari pengadu;

Dewan Kehormatan menjatuhkan putusan berupa penolakan pengaduan dari pengadu yang dijatuhkan apabila ternyata Dewan Kehormatan tersebut tidak menemukan kesalahan pada teradu.

Pengertian penegakan hukum dapat dirumuskan sebagai usaha melaksanakan hukum sebagaimana mestinya, mengawasi pelaksanaannya agar tidak terjadi pelanggaran, dan jika terjadi pelanggaran memulihkan hukum yang dilanggar itu supaya ditegakkan kembali. Penegakan hukum dengan penindakan hukum menurut urutan berikut: ${ }^{34}$

a. Teguran peringatan supaya menghentikan pelanggran dan jangan berbuat lagi (percobaan);

b. Pembebanan kewajiban tertentu (ganti kerugian, denda);

c. Penyisihan atau pengucilan (pencabutan hak-hak tertentu)

d. Pengenaan sanksi badan (pidana penjara, pidana mati).

Sanksi bagi advokat yang melakukan pertanyaan melecehkan ahli di dalam sidang pengadilan

Kasus yang sudah yaitu pengacara Basuki Tjahya Purnama (selanjutnya disebut Ahok) yaitu Humphrey Djemat yang melalukan melecehkan terhadap ahli di dalam persidangan yaitu M'aruf Amin.

Kasus pengacara Jessica Kumala Wongso yaitu Yudi Wibowo terhadap Roni Nitibaskara. Pengacara-pengacara tersebut melakukan melecehkan terhadap keterangan ahli di dalam sidang pengadilan.

34 Edi Krisharyanto,(2006),Fungsi Etika Profesi Hukum Bagi Advokat Dalam Menegakan Hukum, Prespektif, Volume XI No.2 Tahun 2006 April 2006, hlm. 199 
Keterangan ahli sebagai alat bukti pada umumnya, tidak menyangkut pokok perkara pidana yang diperiksa. Keterangan seorang ahli dibutuhkan dalam rangka membuat terang suatu perkara pidana. Keterangan ahli digunakan hakim dalam memeriksa dan memutus suatu perkara untuk memberikan pertimbangan berdasarkan dengan ilmu pengetahuan yang dimiliki oleh ahli tersebut sesuai bidangnya.

Keterangan seorang ahli dapat diberikan dimuka persidangan atau dilakukan pada saat pemeriksaan dalam bentuk suatu laporan sesuai dengan sumpah jabatan yang diucapkan. Keterangan ahli diberikan mengenai seluk beluk perkara pidana yang terjadi sehingga dalam menyampaian harus sesuai dengan syarat dan ketentuan yang berkaitan dengan keterangannya. ${ }^{35}$

Sesuai dengan kasus diatas penindakan dalam Pasal 6 undang-undang advokat dapat di masukkan dalam huruf $b$ dan huruf $\mathrm{c}$.

b. berbuat atau bertingkah laku yang tidak patut terhadap lawan atau rekan seprofesinya;

\footnotetext{
35 Rosalin Inastika Nooryuanto, (2016), Pengaruh Alat Bukti Keterangan Ahli Terhadap Pertimbangan Hakim Perkara Perniagaan Satwa Tanpa Ijin (Studi Putusan Nomor:82/Pid.Sus/2015/PN.Skt), Verstek, Volume 4 No. 3 Desember 2016,Sukoharjo, hlm. 157
}

c. bersikap, bertingkah laku, bertutur kata atau ,mengeluarkan pertanyaan yang menunjukkan sikap tidak hormat terhadap hukum, peraturan perundangundangan, atau pengadilan;

Pasal 7 angka (7) kode etik advokat disebutkan :

(7) Advokat bebas mengeluarkan pertanyaan - pertanyaan atau pendapat yang dikemukakan di dalam sidang pengadilan dalam rangka pembelaan dalam suatu perkara yang menjadi tanggung jawabnya baik dalam sidang terbuka maupun sidang tertutup yang dikemukakan secara proposional dan tidak berkelebihan dan untuk itu memiliki imunitas hukum baik perdata maupun pidana.

Bila pun dari pihak ahli melaporkan perbutan dari Humphrey Djemat sebagai advokat dari Basuki Tjahya Purnama perbuatan dari Humphrey Djemat tersebut dapat dimasukkan kedalam pencemaran nama baika tau penghinaan Pasal 310 KUHP.

$$
\text { Pasal } 310 \text { ayat (1) KUHP }
$$

disebutkan:

(1) barang siapa dengan sengaja merusak kehormatan atau nama baik seseorang dengan jalan menuduh dia melakukan sesuatu perbuatan dengan maksud yang nyata akan tersiarnya tuduhan itu, dihukum karena menista, dengan hukuman penjara selama-lamanya sembilan bulan atau denda sebanyak -banyaknya Rp. 4.500 . 
Menghina yaitu menyerang kehormatan dan nama baik seseorang. Yang diserang itu biasanya merasa malu. Kehormatan yang diserang disini hanya mengenai kehormatan yang dapat dicemarkan karena tersinggung anggota kemaluanya dalam lingkungan nafsu birahi kelamin. Perbuatan yang menyinggung kehormatan dalam lapangan skuil ini tidak termasuk dalam kejahatan, penghinaan , akan tetapi masuk kejahatan kesopanan atau kejahatan yang disebut dalam pasal $281 \mathrm{~s} / \mathrm{d} 303 .^{36}$

Penghinaan ini hanya dapat dituntut apabila ada pengaduan dari orang yang menderita merupakan delik aduan. Penghinaan ini agar seseorang melakukan penghinaan dihukum dengan cara menuduh seseorang telah melakukan perbuatan yang dituduhkan itu tidak perlu suatu perbuatan yang boleh dihukum seperti mencuri, berzina, dan lain sebagainya, cukup dengan perbuatan biasa sudah tentu suatu perbuatan yang memalukan bagi yang berkepentingan untuk diumumkan.

Kejahatan menista ini tidak perlu dilakukan dimuka umum sudah cukup dapat dibuktikan, bahwa terdakwa ada maksud untuk menyiarkan tuduhan itu. Jika penghinaan tersebut berupa

36 R. Soesilo, (1995), Kitab Undang-Undang Hukum Pidana (KUHP), Bogor: Politea,hlm. 225 pengaduan yang bersisi fitnah yang ditujukan kepada pembesar yang berwajib, maka dapat dikenakan Pasal 317 KUHP.

Tindak pidana penghinaan termasuk dalam perbuatan melawan hukum dalam hukum pidana, kesengajaan atau dapat disejajarkan dengan suatu kelalaian advokat dan adanya berakibat menimbulkan suatu kerugian tidak hanya kepada klien dan juga terhdapa pihak lawan yang merasa malu dan dirugikan.

Seorang advokat dilihat dari sukses atau tidaknya dalam membela klienya zaman sekarang dapat dilihat di televesi dan menangani petinggi negeri. Kalau dulu seorang advokat membela rakyat kecil yang berhadapan dengan pemrintah. Padahal bisa jadi perkara yang nilai unagnya besar sesungguhnya mengandung subtansi hukum yang sederhana.

Demi hanya ingin memperoleh nama atau ketenaran kepentingan klien dan kepentingan pihak lawan di kesampingkan. Dengan melontarkan kata-kata atau pertanyaan-pertanyaan yang menyakiti hati dan memandang rendah orang lain di dalam sidang pengadilan. Dengan menyadarai adanya kode etik advokat dan undang-undang advokat maka darinya untuk berusaha menghindari atau menjahui segala bentuk larang-larangan

\section{Penutup}


Berdasarkan uraian dari bab-bab sebelumnya dapat disimpulkan sebagai berikut:

a. Hakikat hak imunitas yang dimiliki advokat dapat kebal hukum selamanya dan tidak selamanya imunitas advokat dapat diberikan secara mutlak pada advokat. Advokat dalam mengeluarkan pendapat - pendapatnya dalam persidangan sesuai dengan iktikad baik maka dapat mempunyai hak imunitas. Advokat tidak boleh mengucapkan kata-kata yang melecehkan pihak lawan terlebih lagi dia seorang ahli di dalam persidangan, melebihi apa yang diperlukan untuk memenuhi tugasnya. Keterangan ahli yang disampaikan di sidang pengadilan menyampaikan keterangannya berdasarkan ilmu pengetahuan yang dimiliknya dan tidak ada akibat hukumnya.

b. Advokat yang diduga atau melakukan suatu perbutan yang melanggar peraturan perundang-undangan dan kode etik advokat dapat diadukan kepada Dewan Kehormatan Oraganisasi Advokat. pihak-pihak yang dirugikan dapat mengadukannya setelah melakukan pengaduan Dewan Kehormatan akan melakukan sidang pertama yang di utamakan perdamain kedua belah pihak jika tidak tercapai akan dilakukan sidang dan diambil ptusan oleh Dewan Kehormatan Organisasi Advokat. Perbuatan advokat yang dikenai penindakan melecehkan keterangan ahli di dalam sidang pengadilan dapat dikenakan penindakan dan pencemaran nama baik. Bila ada pihak yang merasa dirugikan oleh perbuatan advokat tersebut.

\section{E. Daftar Pustaka}

Buku

Agus Yudha Hernoko, (2014), Hukum Perjanjian Asas Proporsionalitas Dalam Kontrak Komersial (edisi Pertama) , Jakarta: PT Kharisma Putra utama

Didik Endro Purwoleksono,(2015), Hukum Acara Pidana,Surabaya: Airlangga University Press

E. Sumaryono, (1995),Etika Profesi Hukum Norma-Norma Bagi Penegak Hukum, Yogyakarta: Kanisius

Frans Hendra Winarta,(1995), Advokat Indonesia, Citra, Idealisme Dan Keprihatinan, Jakarta: Pustaka Sinar Harapan
Hendar Soetarna ,(2011) Hukum Pembuktian Dalam Acara Pidana, Bandung: PT Alumni

Ishaq, (2010),Pendidikan Advokat, Jakarta:

Sinar Grafika 
Jimli Asshiddiqie, (2010),Hukum Acara

Pidana Pengujian Undang-Undang, Jakarta: Sinar Grafika

K. Prent C.M., J. Adisubrata, \& W.J.S.

Poerwadarminta, $\quad$ (1969),Kamus

Latin-Indonesia, Yogyakarta:

Kanisius

Kamus Besar Bahasa Indonesia (Edisi Ketiga), (2002), Pusat Bahasa Departemen Pendidikan Nasional, Jakarta: Balai Pustaka

Munir Fuady,(2005), Profesi Mulia (Etika Profesi Hukum Bagi Hakim, Jaksa, Advokat, Notaris Kurator, Dan Penggurus), Bandung: PT Citra Aditya Bakti

N.E. Algra \& H.R.W. Gokkel. (1983),Kamus Istilah Hukum Fockeman Andre BelandaIndonesia, terjemahan Saleh Adiwinanta S.H. dkk, Bandung: Binacipta

Philipus M. Hadjon dan Tatiek Sri Djatmiati,(2011), Argumentasi Hukum, Yogyakarta: Gajah Mada University Press

Peter Mahmud Marzuki ,(2015), Penelitian Hukum (Edisi Revisi), Jakarta: PT. Adhitya Andrebina Agung

R. Soesilo, (1995), Kitab Undang-Undang Hukum Pidana (KUHP), Bogor: Politea
Satjipto Rahardjo, (2006), Ilmu Hukum, Bandung: PT Citra Aditya Bakti

Supriadi,(2010), Etika \& Tanggung Jawab Profesi Hukum Di Inonesia, Jakarta: Sinar Grafika

Subekti,2005, Hukum Perjanjian, Jakarta : PT Intermasa

Theodorus Yosep Parera,(2016), Advokat Dan Penegak Hukum, Yogyakarta: Genta

V.Harlen Sinaga,(2011), Dasar-Dasar Profesi Advokat,Erlangga

Artikel Jurnal

Isrok,(2009), Advokat Sebagai Penegak Hukum, Varia Peradilan Majalah Hukum, Tahun XXIV No 283 Juni 2009, Ikatan Hakim Indonesia, Jakarta

Solehoddin, (2015),Menakar Hak Imunitas Profesi Advokat, Rechtldee Jurnal Hukum, Vol 10 No.1 Juni 2015,Malang

Agus Raharjo dan Sunaryo,(2014),Penilaian

Profesionalisme Advokat Dalam Penegakan Hukum Melalui Pengukuran Indikator Kinerja Etis,Jurnal Media Hukum, Vol 21 No. 2 Desember 2014,Jawa tengah Edi Krisharyanto,(2006),Fungsi Etika Profesi Hukum Bagi Advokat Dalam Menegakan Hukum, Prespektif , 
Volume XI No.2 Tahun 2006 April 2006

Rosalin Inastika Nooryuanto, (2016), Pengaruh Alat Bukti Keterangan Ahli Terhadap Pertimbangan Hakim Perkara Perniagaan Satwa Tanpa Ijin (Studi Putusan Nomor:82/Pid.Sus/2015/PN.Skt), Verstek, Volume 4 No. 3 Desember 2016,Sukoharjo

\section{World Wide Web}

MK Tegaskan Imunitas Advokat Di Dalam dan Luar Pengadilan, (2017) ,Tersedia pada http://www.mahkamahkonstitusi.go.i d/index.php?page $=$ web. Berita\&id=9 899\#.Whp7JZdx3IU, [Akses pada tanggal 23 september 2017].

Hak Imunitas Advokat Tergantung Iktikad Baik , (2017),Tersedia pada: http://www.hukumonline.com/berita/ baca/hol15478/hak-imunitasadvokat-tergantung-iktikad-baik, , [Akses pada tanggal 09 mei 2017]

MUI: Tindakan Ahok dan Pengacaranya Terhadap Ma'aruf Amin Brutal, (2017), Tersedia Pada: https://nasional.sindonews.com/read/ $\underline{1177025 / 13 / m u i-t i n d a k a n-a h o k-d a n-~}$ pengacaranya-terhadap-maruf-aminbrutal-1486204867, , [Akses pada tanggal 18 Mei 2017].

Ungkap Sisi Buruk Jessica, Pengacara “Semprot”Saksi Ahli, (2017) Tersedia Pada: http://news.okezone.com/read/2016/ 09/01/338/1478570/ungkap-sisiburuk-jessica-pengacara-semprotsaksi-ahli, [Akses pada tanggal 18 Mei 2017]

http://www.sinonimkata.com/sinonim156122-melecehkan.html, [Akses pada tanggal 07 September 2017] 